\title{
Pemanfaatan Realtime Database di Platform Firebase Pada Aplikasi E-Tourism Kabupaten Nabire
}

\author{
Edwin Adrin Wihelmus Sanadi*1, Andani Achmad ${ }^{1}$, Dewiani ${ }^{1}$ \\ ${ }^{1}$ Departemen Teknik Elektro, Fakultas Teknik, Universitas Hasanuddin \\ J1. Poros Malino Km. 6, Bontomarannu, Kabupaten Gowa, Sulawesi Selatan, 92171 \\ *Email: edwinsanadi812@gmail.com
}

DOI: 10.25042/jpe.052018.04

\begin{abstract}
Abstrak
Objek wisata yang berada di kabupaten Nabire relatif belum banyak dikembangkan dan belum ditangani secara optimal yang disebabkan karena kurangnya promosi. E-Tourism yang merupakan sebuah aplikasi elektronik untuk sektor pariwisata yang dapat memudahkan pengguna mengunjungi situs wisata pada sebuah lokasi. Aplikasi yang tersedia saat ini tidak dapat melakukan perubahan data secara real-time mengenai posisi koordinat pengguna aplikasi untuk mengetahui keberadaannya dalam mencari tempat wisata.Penelitian ini bertujuan untuk memberikan informasi kepada pengguna aplikasi mengenai posisi letak wisata dan posisi pengguna yang dapat berubah secara real-time dengan menggunakan firebase. Penelitian ini menggunakan metode eksperimental, yaitu menyematkan platform firebase pada E-Tourism sehingga aplikasi dapat memanfaatkan berbagai fitur real-time database di firebase. Sistem diuji dengan memindahkan posisi pengguna aplikasi untuk melihat perubahan data posisi secara real-time dan akan ditunjukkan pada peta aplikasi. Pengujian berikutnya dengan menampilkan lokasi pariwisata serta jalur yang ditempuh oleh pengguna untuk mencapai tempat wisata tersebut.Hasil penelitian ini menampilkan posisi pengguna yang dapat berubah secara real-time ketika pengguna melakukan perpindahan posisi tanpa harus melakukan penyegaran data secara manual (refresh). Aplikasi pun dapat menampilkan daftar lokasi wisata serta jalur yang ditempuh untuk menuju lokasi wisata yang terdapat di kabupaten Nabire.
\end{abstract}

\begin{abstract}
Utilization of Realtime Database on Firebase Platform in E-Tourism Applications in Nabire Regency. Tourism objects in the district of Nabire relatively not developed much and has not been handled optimally due to lack of promotion. ETourism which is an electronic application for the tourism sector that can facilitate the user to visit a tourist site at a location. The currently available apps can not make real-time data changes regarding the position of the app's user coordinates to find out where to find the sights. This study aims to provide information to application users about the position of the location of the tour and the position of users who can change in real-time using firebase. This research uses experimental method, that is pinned firebase platform on E-Tourism so that application can utilize various real-time database feature in firebase. The system is tested by moving the user's position of the app to see changes in position data in real-time and will be shown on the application map. The next test by showing the location of tourism as well as the path traveled by the user to reach the sights. The results of this study show the position of the user that can change in real-time when the user to switch position without having to refresh the data manually (refresh). Applications can also display a list of tourist sites and the path taken to get to the tourist sites located in Nabire district.
\end{abstract}

Kata Kunci: E-Tourism, Firebase, Real Time.

\section{Pendahuluan}

Teknologi informasi telah menjadi komponen penting dalam berbagai bidang, termasuk industry pariwisata. Obyek wisata yang berada di Kota Nabire relatif belum banyak dikembangkan dan belum ditangani secara optimal. Secara umum terdapat suatu kendala yang menjadi hambatan dalam mengembangkan sektor pariwisata bagi Pemerintah Kota Nabire yaitu bentuk promosi yang dilakukan belum optimal. Pemanfaatan teknologi informasi pada bidang pariwisata dapat dijadikan sebagai media promosi untuk memperkenalkan objek wisata melalui website dan pembuatan aplikasi sistem informasi geografis. $E$ tourism merupakan sebuah aplikasi elektronik yang bergerak pada sector pariwisata yang memudahkan pengguna untuk mengunjungi sebuah situs wisata pada sebuah negara. 
Terdapat beberapa penelitian dalam pengembangan E-Tourism seperti menambahkan fitur audio-visual seperti yang terdapat pada $E$ Tourism Disporabudpar Kabupaten Majalengka [1]. Fitur semantic web juga pernah diterapkan untuk etourism di Indonesia [2]. Namun aplikasi yang tersedia saat ini tidak dapat melakukan perubahan data secara realtime mengenai posisi koordinat pengguna aplikasi untuk mengetahui keberadaannya dalam mencari tempat wisata.

Firebase merupakan platform untuk aplikasi realtime. Ketika data berubah, maka aplikasi yang terhubung dengan firebase akan meng-update secara langsung melalui setiap device (perangkat) baik website ataupun mobile [3]. Firebase mempunyai library (pustaka) yang lengkap untuk sebagian besar platformweb dan mobile dan dapat digabungkan dengan berbagai framework lain seperti node, java, javascript, dan lain-lain. Application Programming Interface (API) untuk menyimpan dan sinkronisasi data akan disimpan sebagai bit dalam bentuk JSON (JavaScript Object Notation) pada cloud dan akan disinkronisasi secara realtime [4]. Terdapat beberapa fitur yang disediakan oleh firebase adalah sebagai berikut :

- Analytics, dapat mengamati tingkah laku pengguna dalam penggunaan aplikasi dan ditampilkan dalam satu dashboard.

- Develop, terbagi menjadi beberapa fitur seperti cloud messaging, authentication, realtime database, storage, hosting, testlab dan crash reporting.

- Grow, untuk mempublikasikan sebuah produk aplikasi.

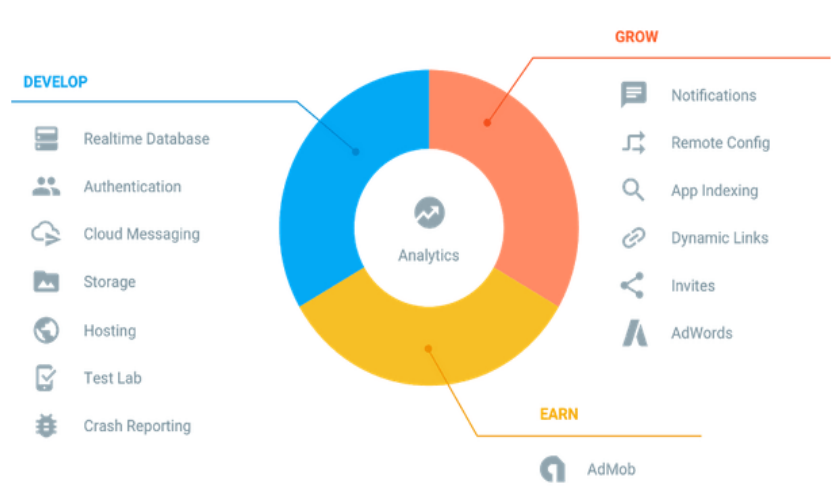

Gambar 1. Fitur firebase

Firebase Realtime Database merupakan basis data online yang dapat digunakan sebagai media penyimpanan data dari aplikasi. Data disimpan dalam bentuk JSON dan dapat disinkronkan secara realtime ke setiap client yang terhubung. Layanan ini memiliki 3 kemampuan inti yaitu :

- Realtime, jika terdapat perubahan pada data database, maka seluruh client yang terhubung secara otomatis akan mendapatkan perubahannya dengan cepat [4].

- Offline, yaitu aplikasi yang menggunakan fitur ini akan tetap responsif bahkan saat dalam keadaan luring. Hal ini disebabkan karena Firebase SDK (Software Development Kit) dapat mempertahankan data dan perubahannya pada media penyimpanan client. Pada saat client terhubung ke jaringan internet, maka Firebase SDK akan melakukan penyesuaian otomatis atas catatan perubahan data yang disimpan pada media penyimpanan client dengan kondisi terkini dari Firebase Server.

- Accessible from client devices. Layanan ini menawarkan kemudahan untuk mengakses firebase realtime database secara langsung dari sebuah perangkat mobile atau sebuah peramban web tanpa membutuhkan server application.

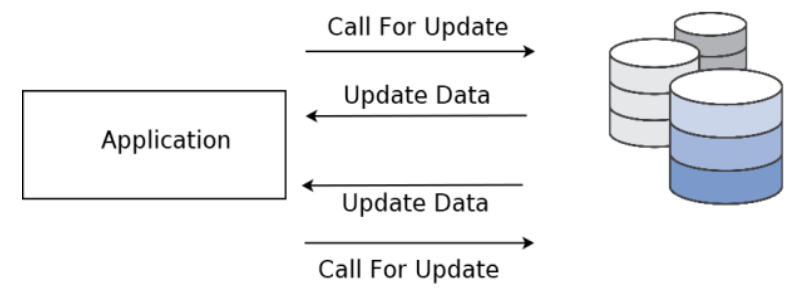

Gambar 2. Gambaran pemanggilan database tradisional
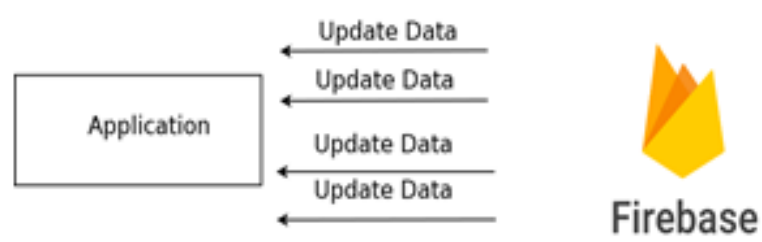

Gambar 3. Gambaran pemanggilan firebase database

Database milik firebase merupakan database yang bersifat non-relational atau NoSQL, dimana database ini merupakan jenis database yang tidak menggunakan sistem tabel dalam implementasinya serta tidak menyimpan data secara lokal pada perangkat melainkan pada awan. 
Selain itu, firebase database juga memiliki optimisasi dan fungsionalitas yang berbeda bila dibandingkan dengan basis data relasional.

\section{Metodologi Penelitian}

Tahapan metodologi penelitian yang digunakan adalah pengumpulan studi literature, perancangan, analisa kebutuhan, perancangan sistem, implementasi, pengujian dan pengambilan keputusan. Adapun diagram alir metodologi penelitian dapat dilihat pada Gambar 4.

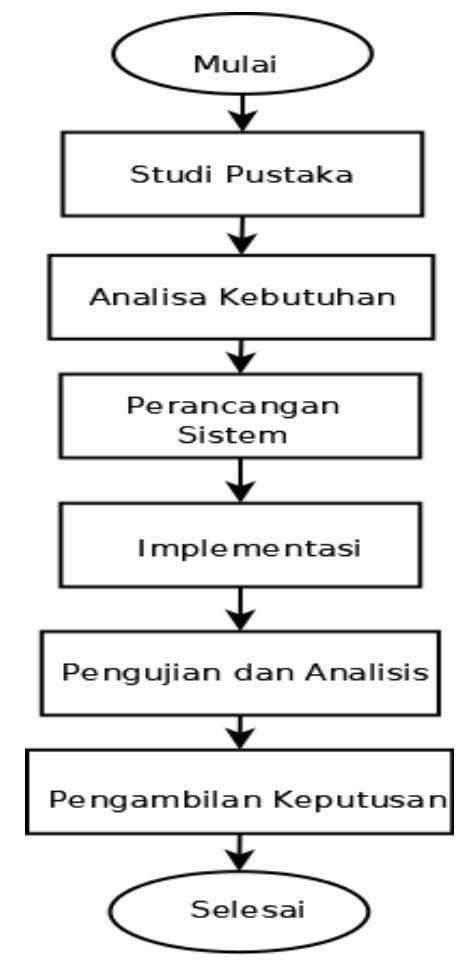

Gambar 4. Diagram alir metodologi penelitian

\subsection{Lokasi dan Waktu Penelitian}

Penelitian ini dilakukan di Lab Pusat Teknologi Informasi dan Pangkalan Data Universitas Islam Negeri Alauddin. Waktu Penelitian dilakukan selama 2 bulan yaitu bulan Oktober 2017 sampai bulan Desember 2017.

\subsection{Sumber Data}

Data yang digunakan pada penelitian ini adalah sebuah API yang berisi data-data tempat wisata yang tersimpan dalam bentuk JSON di firebase yang terdiri dari id, nama wisata, deskripsi dan koordinat lokasi.

\subsection{Rancangan Penelitian}

Rancangan penelitian memiliki beberapa tahapan sesuai dengan metode waterfall [4]. Pertama, Studi literatur : pada tahap ini dilakukan dengan cara mengunjungi perpustakaan untuk mencari referensi berupa buku, tesis atau pun jurnal yang berhubungan dengan topik penelitian. Selain itu, studi literatur juga dilakukan dengan cara online atau mengunjungi suatu website. Kedua, Analisis Kebutuhan Sistem: pada tahapan ini peneliti melakukan analisa terhadap sistem, apa saja yang menjadi kebutuhan sistem yang akan dirancang, seperti software, hardware atau sistem operasi, dan sebagainya. Dan untuk mendapatkan informasi tersebut, peneliti melakukan diskusi dan studi literatur. Ketiga, Desain Sistem: pada tahapan peneliti mendesain antarmuka aplikasi, dan model database yang akan digunakan. Keempat, Penulisan Kode Program: Kode program menggunakan bahasa pemrograman Type Script dengan basis data MongoDB yang berkonsep NoSQL. Dan yang terakhir, Pengujian Sistem: sistem diuji dengan menggunakan teknik pengujian black box. Setiap fungsional yang ada pada sistem diuji kinerjanya untuk mendapatkan sistem yang berkualitas [5].

\subsection{Metode Pengumpulan Data}

Sumber data diperoleh dari sebuah API yang berisi koordinat dari tempat wisata di kabupaten nabire. Kemudian data tersebut dipindahkan ke firebase database realtime agar aplikasi dapat diakses dengan menggunakan fasilitas firebase. Data API terdiri dari id_lokasi,namalokasi dan koordinat lokasi.

\subsection{Analisis Data}

Data yang didapatkan berupa hasil dari penginputan data wisata dan posisi terakhir pengguna aplikasi untuk keperluan pelacakan. Data yang didapatkan kemudian dianalisis untuk membuktikan kinerja dari firebase databaserealtime dalam hal pemutakhiran data.

\section{Perancangan Sistem}

Perancangan sistem terdiri dari beberapa tahapan yaitu perancangan diagram use case, 
arsitektur sistem dan perancangan basis data. Perancangan diagram use case mengacu pada analisis kebutuhan.

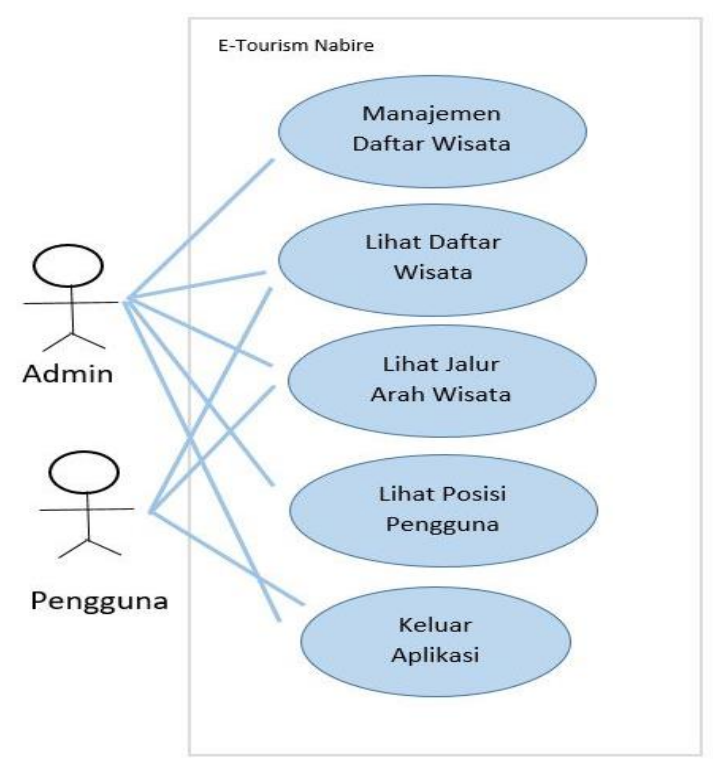

Gambar 5. Use case diagram aplikasi

Use case diagram di atas menunjukkan proses data yang akan berjalan pada aplikasi yang akan dikembangkan. Seluruh proses hak akses untuk melihat daftar wisata, detail, jalur ke daerah wisata, dan posisi terakhir dapat dilakukan tanpa harus melakukan proses autentikasi. Sedangkan untuk admin harus melalui proses autentikasi untuk melakukan proses manajemen data wisata.

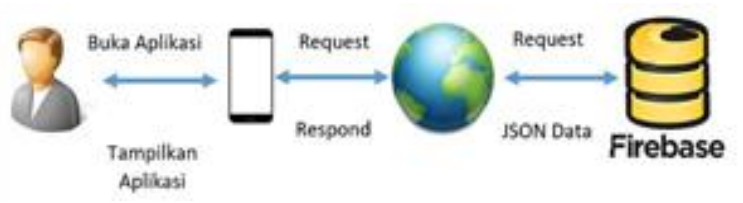

Gambar 6. Perancangan arsitektur sistem

Pada perancangan arsitektur sistem, membahas mengenai pertukaran data dari sistem yang akan digunakan untuk menampilkan data sesuai permintaan pengguna yang didapatkan dari firebase database.

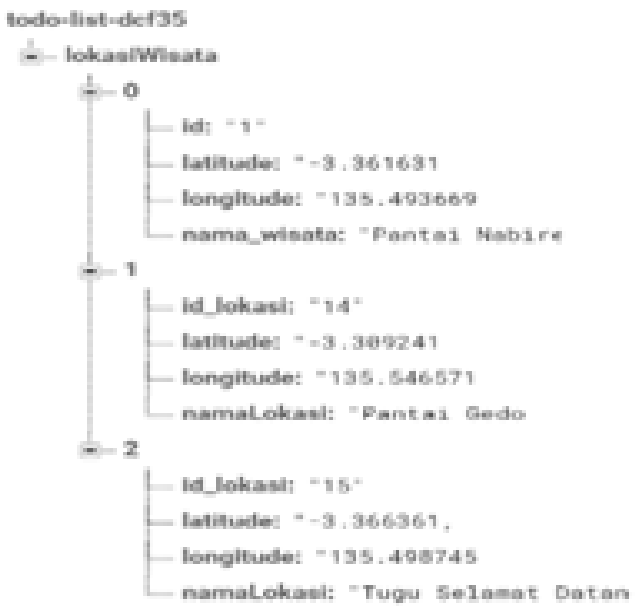

Gambar 7. Rancangan database sistem

\section{Hasil Penelitian}

Pada proses antar muka $e$-tourism ada beberapa pilihan yang mendukung proses kerja sistem. Secara singkat proses ini adalah sebagai berikut : Proses konfigurasi firebase, pembuatan basis data, penginputan data, dan proses perubahan data posisi pengguna. Adapun tahapan-tahapan yang dilakukan dalam membangun aplikasi yaitu :

\subsection{Proses Konfigurasi Firebase}

Tahapan ini dilakukan dengan mengakses situs firebase kemudian memilih pengaturan dan aplikasi web. Tahapan ini akan didapatkan hasil berupa data konfigurasi firebase untuk dipasangkan ke aplikasi.

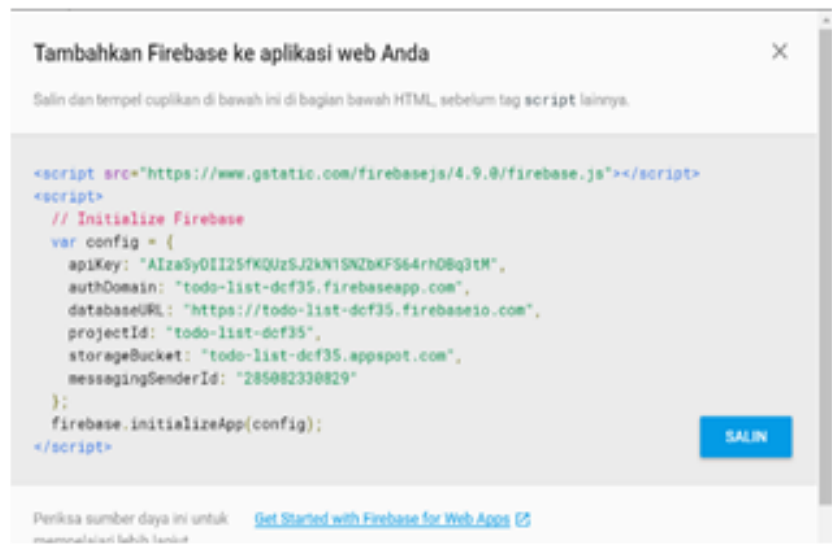

Gambar 8. Konfigurasi firebase 


\subsection{Proses Pembuatan Database}

Pada halaman console firebase, pilih menu database. Kemudian tuliskan nama database yang akan digunakan untuk aplikasi. Untuk penelitian ini, akan menggunakan 2 database yaitu lokasi Wisata untuk menampung daftar wisata dan posisi terakhir untuk menampung data posisi terakhir pengguna aplikasi.

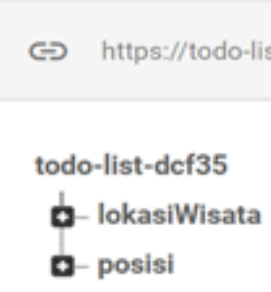

Gambar 9. Database lokasiWisata dan posisi

\subsection{Proses Autentikasi aplikasi}

Proses autentikasi digunakan untuk memvalidasi pengguna yang berhak menggunakan aplikasi. Pengguna memasukkan nama akun dan kata sandi kemudian aplikasi akan mengirimkan data ke firebase untuk mencocokkan data pengguna.
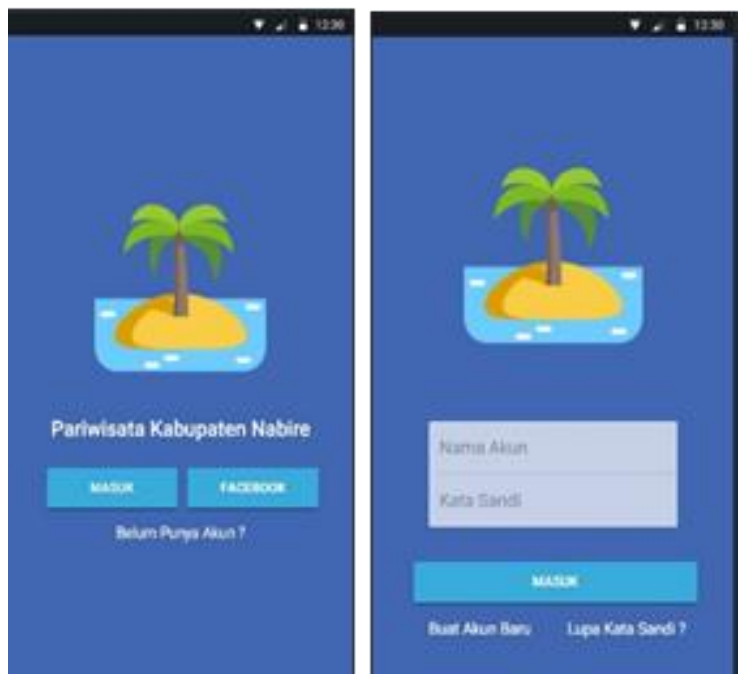

Gambar 10. Halaman autentikasi aplikasi

\subsection{Halaman Utama}

Ketika pengguna telah berhasil melakukan autentikasi, maka aplikasi akan mengarahkan ke halaman utama yang terdiri dari beberapa menu yang dapat diakses oleh pengguna.

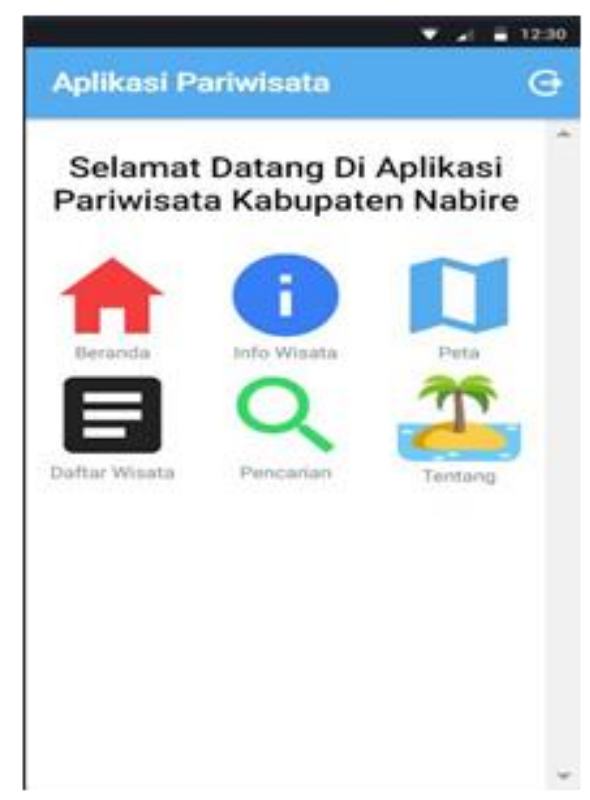

Gambar 11. Halaman utama aplikasi

\subsection{Proses Penginputan Data Wisata}

Proses penginputan dilakukan pada e-tourism. Data yang diinput adalah data wisata. Inputan yang disediakan adalah lokasi_wisata, latitude, dan longitude.

Hasil dari penginputan data akan tersimpan secara realtime di firebase database, seperti terlihat pada Gambar berikut.

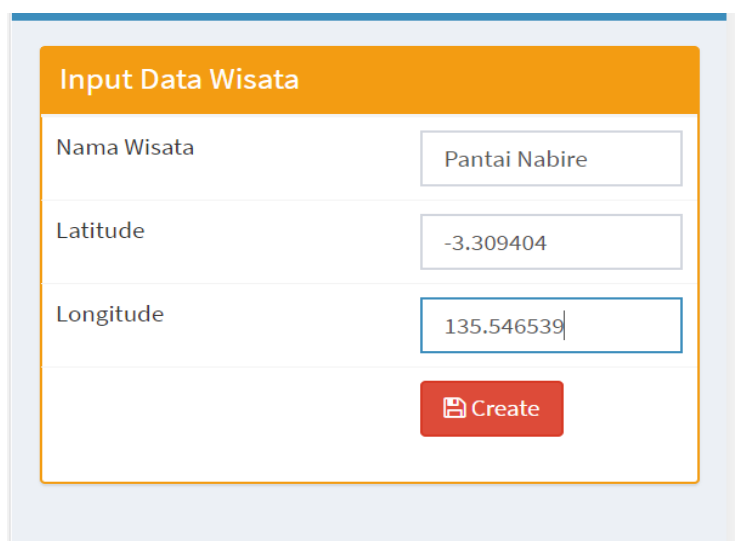

Gambar 12. Formulir penginputan data wisata

\subsection{Peta Sebaran Lokasi Wisata}

Halaman ini menampilkan sebaran lokasi wisata dalam bentuk peta. Data didapatkan dari database firebase yang dapat berubah secara realtime. 


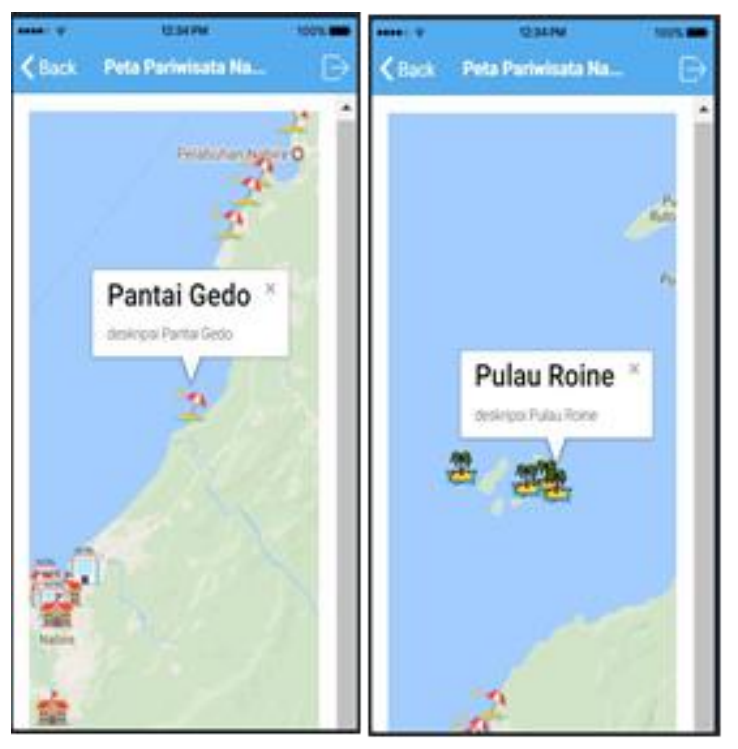

Gambar 14. Peta sebaran wisata

\subsection{Proses Perubahan Data Posisi Pengguna}

Sistem yang dibangun dilengkapi dengan pendeteksian posisi pengguna dengan bantuan GPS (global positioning system). Pengguna memulai proses tracking di aplikasi dengan mengirim koordinat posisi terakhir pengguna ke firebase database realtime.

Hasil dari penginputan data posisi terakhir tersimpan secara realtime di firebase database, seperti terlihat pada Gambar berikut.

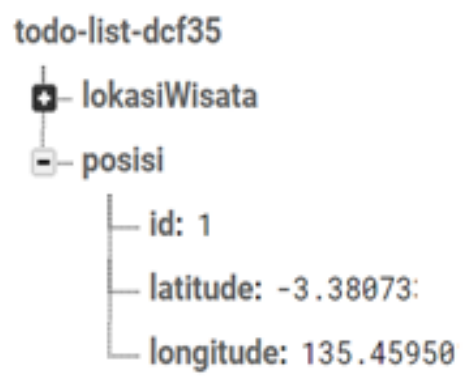

Gambar 15. Isi database posisi terakhir

\subsection{Proses Tampil Jalur Menuju Lokasi Wisata}

Proses ini dilakukan dengan mengambil data posisi data dan daftar lokasi wisata yang tersimpan di firebase database realtime. Apabila pengguna memilih sebuah tempat wisata, maka sistem akan mengambil informasi detail dari tempat wisata tersebut seperti nama wisata, latitude, dan longitude.

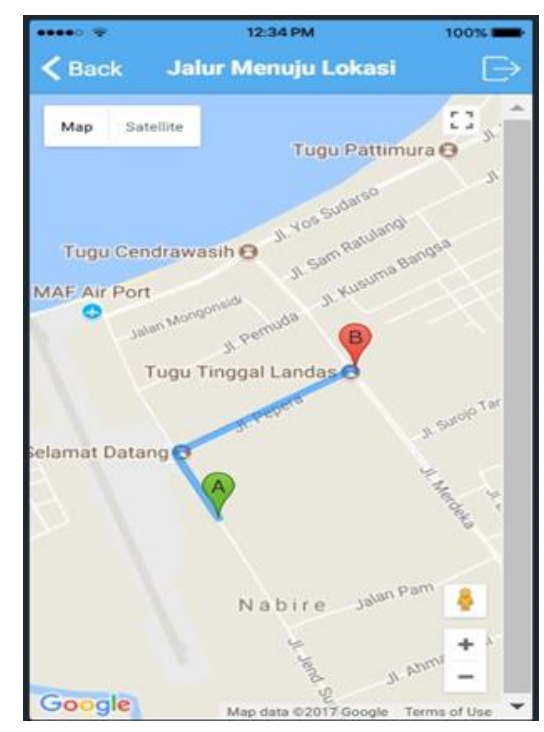

Gambar 16. Jalur menuju lokasi wisata

\section{Pembahasan}

Penelitian ini memperlihatkan hasil dari implementasi pemanfaatan firebase database realtime yang mampu melakukan penginputan dan pemutakhiran data secara realtime. Pengguna tidak menggunakan fitur refresh (penyegaran halaman) untuk melihat perubahan data secara langsung. $E$ tourism yang dihasilkan juga mampu menampilkan sebaran daftar wisata dalam bentuk peta serta mampu menampilkan jalur untuk menuju ke kawasan wisata tersebut.

\section{Kesimpulan}

Pemanfaatan firebase database realtime dalam pengembangan aplikasi web dapat menjadi solusi bagi para pengembang. Dengan fitur databaserealtime, aplikasi dapat menampilkan informasi yang lebih cepat dan realtime. Hasil perubahan yang terdapat pada firebase realtime database, secara otomatis akan disalurkan ke client yang terhubung dengan aplikasi tanpa harus melakukan aksi refresh (penyegaran halaman).

\section{Referensi}

[1] Ade Bastian, Sandi Fajar Rodiansyah, Rekta Rezanova, "Pengembangan E-Tourism Disporabudpar Kabupaten Majalengka Menggunakan Metode SWOT", Seminar Nasional Teknologi Informasi dan Komunikasi 2017 (SENTIKA 2017).

[2] Theophilus Wellem, "Semantic Web Sebagai Solusi Masalam Dalam E-Tourism di Indonesia", Seminar 
Nasional Aplikasi Teknologi Informasi 2009 (SNATI 2009) Yogyakarta.

[3] Firebase, "Firebase Product", diunduh [4 November 2017] melalui https://firebase.google.com/products/.

[4] Dinesh Rawal, "Traditional Infrastructure vs Firebase Infrastructure", International Journal for Scientific
Research \& Development|(IJSRD), Vol.5, Issue 4, 2017.

[5] Shashank Gupta, Bhaskar Kapoor, "Firebase In App Development", International Research Journal of Engineering and Technology (IRJET), Vol.3, Issue 12, 2016. 